OPEN ACCESS

Edited by:

Luke P. Miller,

San Diego State University,

United States

Reviewed by:

Nicolas Urbina-Cardona,

Pontifical Javeriana University,

Colombia

Sumudu Rubasinghe,

University of Peradeniya, Sri Lanka

*Correspondence:

Simeon Bezeng Bezeng

bezengsimmy@gmail.com

Specialty section:

This article was submitted to

Ecophysiology,

a section of the journal

Frontiers in Ecology and Evolution

Received: 31 March 2021

Accepted: 23 July 2021

Published: 11 August 2021

Citation:

Dayananda B, Bezeng SB, Karunarathna S and Jeffree RA (2021)

Climate Change Impacts on Tropical

Reptiles: Likely Effects and Future

Research Needs Based on Sri Lankan

Perspectives.

Front. Ecol. Evol. 9:688723.

doi: 10.3389/fevo.2021.688723

\section{Climate Change Impacts on Tropical Reptiles: Likely Effects and Future Research Needs Based on Sri Lankan Perspectives}

\author{
Buddhi Dayananda ${ }^{1}$, Simeon Bezeng Bezeng ${ }^{2,3 *}$, Suranjan Karunarathna ${ }^{4}$ and \\ Ross A. Jeffree ${ }^{5}$ \\ ${ }^{1}$ School of Agriculture and Food Sciences, The University of Queensland, Brisbane, QLD, Australia, ${ }^{2}$ Department \\ of Geography, Environmental Management and Energy Studies, University of Johannesburg, Johannesburg, South Africa, \\ ${ }^{3}$ Department of Life and Consumer Sciences, University of South Africa, Johannesburg, South Africa, ${ }^{4}$ Nature Explorations \\ and Education Team, Moratuwa, Sri Lanka, ${ }^{5}$ Jeffree Conservation \& Research, Sydney, NSW, Australia
}

The tropical island nation of Sri Lanka has a rich terrestrial and aquatic reptilian fauna. However, like most other tropical countries, the threat of climate change to its reptile diversity has not been adequately addressed, in order to manage and mitigate the extinction threats that climate change poses. To address this shortfall, a review of the international literature regarding climate change impacts on reptiles was undertaken with specific reference to national requirements, focusing on predicted changes in air temperature, rainfall, water temperature, and sea level. This global information base was then used to specify a national program of research and environmental management for tropical countries, which is urgently needed to address the shortcomings in policyrelevant data, its availability and access so that the risks of extinction to reptiles can be clarified and mitigated. Specifically, after highlighting how climate change affects the various eco-physiological features of reptiles, we propose research gaps and various recommendations to address them. It is envisaged that these assessments will also be relevant to the conservation of reptilian biodiversity in other countries with tropical and subtropical climatic regimes

Keywords: extinction, point endemic, range restricted, temperature, climate warming, reptiles

\section{INTRODUCTION}

Climate change now looms as one of the greatest threats to global biodiversity as well as a formidable force of global environmental change (Evans, 2019; Kellogg, 2019). It is already exerting substantial adverse impacts on different hierarchies of the biosphere. As the atmospheric concentrations of carbon dioxide and other greenhouse gases continue to increase, it is predicted that climate change will cause distributional shifts, phenological modifications, and altered interactions in biological communities. In addition, climate change is expected to accentuate species extinction rates and lead to impairment of ecosystem functions in the coming decades (Ackerman, 1980; Pounds et al., 1999; Walther et al., 2002; Thomas et al., 2004; Brondizio et al., 2019).

The scientific community is constantly evaluating the vulnerability of organisms and ecosystems to climate change and formulating mitigation and response strategies that maybe implemented 
to minimize the compounding effects of climate change (Lee and Jetz, 2008). This is particularly true for tropical island nations like Sri Lanka; ranked as one of the world's biodiversity hotspots due to its rich reptile diversity-with 235 described species, of which 63.4\% are endemic (de Silva and Ukuwela, 2017; Karunarathna et al., 2019). Moreover, reptiles as a phylogenetic group have been relatively neglected in biodiversity conservation studies in general, relative to mammals, birds and amphibians, and are clearly in need of greater priority (Gumbs et al., 2018) in relation to climate change impacts.

Key approaches which have been identified as holding promise include the identification of resilient landscapes and climate refugia for native wildlife, carbon-neutral and alternative-energy initiatives, green infrastructure and low-impact development, landscape-scale conservation planning, and sustainable use of natural resources and energy sources (Bickford et al., 2010). However, financial and human resources available for such initiatives are severely limited within a global economy based on immediate monetary gains coupled with conservative sociopolitical views in both developing and developed nations. Together with many other issues, these factors give rise to low national and international priorities for biodiversity conservation. Given these current economic and political constraints, the most significant challenges for conservation authorities and natural resource managers in the near future are; (i) the identification of species and ecosystems which are most vulnerable to climate change, (ii) assessing species responses to climate change, and (iii) the prioritization of planned conservation actions and responses.

In the 2008 Review of The IUCN Red List of Threatened Species, Foden et al. (2008) introduced the major characteristics that increase an organism's susceptibility to future climate change (but see also review by Bellard et al., 2012). These characteristics of vulnerable species are broadly classified as follows: (1) a highly specialized set of niche dimensions such as unique habitat/resource needs or micro-environmental conditions; (2) narrow environmental tolerances or thresholds; (3) life histories that depend on environmental cues/triggers which are disrupted by climate change; (4) obligatory mutualistic and other forms of symbiotic interspecific interactions which are likely to be disrupted by climate change; (5) poor ability to disperse to or colonize suitable new habitats; and (6) species with a high site fidelity (adapted from Foden et al., 2008).

Several tropical species share one or more of the above features pointing to their enhanced vulnerability to climate changeinduced threats. Moreover, numerous studies based on both long-term field surveys and bioclimatic modeling have suggested that tropical ecosystems are likely to be severely impacted by climate change (Hughes, 2000). However, the impacts of climate change on tropical biota remain relatively understudied, and most existing studies focus on south and central American tropical biomes. In contrast, South-Asian tropical biomes have only attracted minimal attention in the climate change literature, and this is particularly the case for the rich biodiverse Indian Oceanic tropical island nation of Sri Lanka. With respect to reptilian diversity in Sri Lanka, nine chelonian species in six families (five marine turtles, three freshwater terrapins, and one land tortoise) are recognized, of which one species (red eared terrapin, Trachemys scripta) has been introduced through the pet trade (Karunarathna et al., 2017). Two species of native crocodile and 118 lizard species are found in the country, and of these, 96 species are endemic to Sri Lanka. Among the 118 lizard species, the species-rich families are the Gekkonidae (59 species), Scincidae (32 species), and the Agamidae (21 species) with six endemic genera (Ceratophora, Chalcidoseps, Cophotis, Lankascincus, Lyriocephalus, and Nessia). Furthermore, 106 snake species occur in the island of which 51 species are endemic, including the genus Aspidura (de Silva and Ukuwela, 2017; see Figure 1 and Table 1).

In this review, we outline the likely main effects of climate change on reptiles in tropical Sri Lanka with specific reference to changes in air temperatures, rainfall patterns, water temperatures, and sea levels. We also identify the current research gaps and the requirements for future research which are needed to better characterize the most vulnerable reptilian species. As this study provides a body of information to better identify the most vulnerable species of reptiles, it is envisaged as being of benefit to wildlife managers in their choice of the most appropriate management strategies to mitigate climate change impacts for the conservation of reptiles in tropical and sub tropical countries.

Furthermore, such a review for the island of Sri Lanka with its geographic location, small land area, and rich biodiversity is likely to be relevant to other tropical and subtropical regions such as Costa Rica, Caribbean Islands, Southern Florida and Florida Keys, south and central Pacific islands, and the Indo-Malayan region, which have also been identified as areas that need critical conservation planning in the face of climate change. For example, Day (2009) highlighted a range of challenges linked to the scarcity of biodiversity data for the understanding of the impacts of climate change on biodiversity in the Caribbean Islands, which are needed for the development of more effective species conservation action strategies. Thus, a review of the potential impact of climate change on reptiles in tropical countries may initiate some national-level actions while drawing attention from the international scientific community. In the absence of peerreviewed eco-physiological studies on Sri Lankan herpetofauna, we synthesized all the scientific literature used in Angilletta (2009); Dayananda et al. (2016), and Noble et al. (2017) in order to articulate the comprehensive and critical views of the reptilian eco-physiological knowledge gaps and future research needs in relation to current and future climate change scenarios.

\section{CLIMATE CHANGE IMPACTS ON THE ECO-PHYSIOLOGY OF REPTILES}

\section{Effects of Changes in Rainfall and Monsoonal Patterns}

In Sri Lanka, the monsoon system has already been observed to have changed appreciably and seasonal rainfall anomalies are already evident (Zubair et al., 2008; Burt and Weerasinghe, 2014). A decrease in the frequency of rainfall, drier periods than previously and increases in the intensity of extreme rainfall 

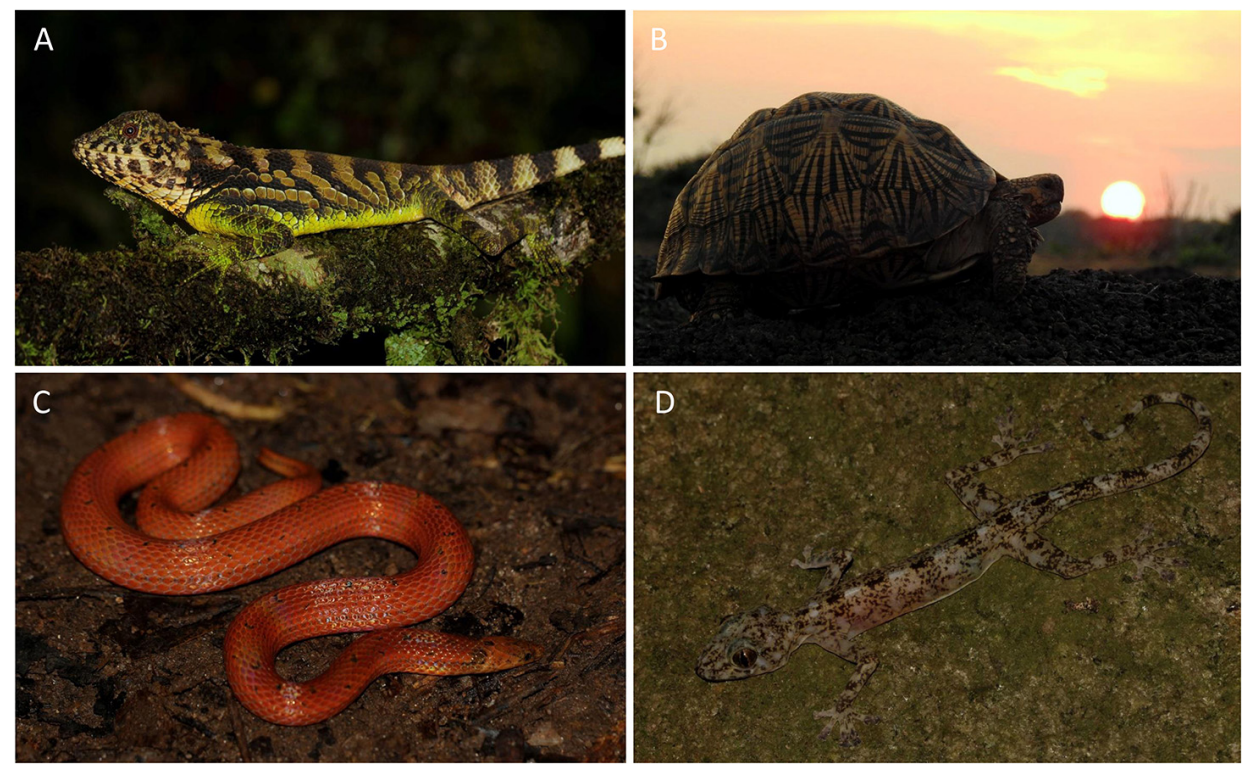

FIGURE 1 | Climatically restricted and threatened reptile species in Sri Lanka. (A) Ceratophora erdeleni-a critically endangered and endemic lizard species restricted to the $80 \mathrm{~km}^{2}$ land area in Rakwana hill zone. (B) Geochelone elegans-a near threatened land tortoise that is found in Dry and Intermediate zone. (C) Aspidura brachyorrhos-a vulnerable and represent an endemic genus of non-venomous snake species that is found in Central Heighland zone. (D) Calodactylodes illingworthorum-a vulnerable and endemic gecko found in Uva Savannah zone (please refer to the reptile zone map in Figure 2A).

events are now evident, including an increased frequency of flooding; these trends are expected to continue and intensify. Moisture regimes, including factors of soil hydrology, humidity, and the hydrologic characteristics of wetlands and aquatic habitats, are crucial environmental factors that govern the embryonic development of reptiles. Water exchange by eggs with the surrounding environment is particularly important during the incubation process (Warner et al., 2011). For example, freshwater turtles select well-drained, moist soil for their egglaying in close proximity to wetlands. Similarly, crocodiles and alligators nest adjacent to large, permanent water bodies. With the observed trends in climate change, many areas of the world that are rich in reptile fauna, including Sri Lanka, are getting drier and moisture-stressed (Bickford et al., 2010). As a result, oviparous reptiles can be expected to suffer from egg dehydration which can in turn lead to decreased hatching success and small hatchling size; small-sized juveniles can subsequently suffer increased predation and can be weak in their abilities for dispersal and general motility (Angilletta, 2009). Dehydrationinduced physiological stressors during embryonic development may well have adverse, long-term fitness consequences, such as slow growth and development (Ackerman, 1991; Miller and Packard, 1992; Belinsky et al., 2004). Thus, among the Sri Lankan herpetofauna, the following species are identified as likely to suffer from similar climate-driven adversities; the two species of terrapins (native Melanochelys trijuga and endemic Lissemys ceylonensis), the two species of crocodiles (Crocodylus palustris and Crocodylus porosus) and 13 species of snakes (Amphiesma stolatum, Aspidura brachyorrhos, Aspidura copei, Aspidura ceylonensis, Aspidura deraniyagalae, Aspidura desilvai, Aspidura drummondhayi, Aspidura guentheri, Aspidura ravanai,
Aspidura trachyprocta, Atretium schistosum, Fowlea asperrimus, and Fowlea piscator) (Karunarathna et al., 2019).

\section{Effects of Air Temperature Increments}

One of the most direct and predictable effects of climate change is an increase in mean air temperature which has also been clearly identified as a major threat to reptiles in coming years (Stocker et al., 2013). Being poikilotherms, reptiles are sensitive to changes in their thermal landscape, thus rising atmospheric temperature may lead to changes in reptilian metabolism (Araújo et al., 2006; Tewksbury et al., 2008; Sinervo et al., 2010). Reptiles depend on external environmental temperatures to optimize their body temperature $\left(\mathrm{T}_{b}\right)$, and then their physiological performance and behavioral activities (Huey et al., 2012) such as locomotion, digestion, growth, and reproduction are strongly influenced by environmental temperatures (Huey and Bennett, 1987; Huey and Kingsolver, 1989; Hoffmann et al., 2013). Continued climate warming is thus expected to further push environmental thermal regimes beyond the optimal range to which many reptiles have become adapted. Moreover, recent studies have verified that climate change poses a serious threat to reptile populations (Araújo et al., 2006; Tewksbury et al., 2008; Sinervo et al., 2010; Huey et al., 2012). Changes in environmental temperature can alter the body temperature $\left(\mathrm{T}_{b}\right)$ of reptiles and thus their physiological performance, which is closely linked to their vulnerability to extinction (Pounds et al., 1999; Root et al., 2003; Thomas et al., 2004; Araújo et al., 2006; Wake, 2007; Bickford et al., 2010; Huey et al., 2010, 2012; Vitt and Caldwell, 2013).

Many tropical reptile species are known to exist close to their physiological thermal optima. Moreover, tropical environments confer a greater degree of temporal thermal stability. Therefore, 
TABLE 1 | Reptile families in Sri Lanka with their geographical distributional zones (please refer to the reptile zones map in Figure 2A), number of species and current conservation status ( $\mathrm{CR}=$ Critically Endangered, EN = Endangered and VU = Vulnerable; After Ministry of Mahaweli Development and Environment, 2019).

\begin{tabular}{|c|c|c|c|c|c|c|c|c|c|c|c|c|c|c|}
\hline \multirow[b]{2}{*}{$\begin{array}{c}\text { Total } \\
\\
\text { Families }\end{array}$} & \multirow[b]{2}{*}{ 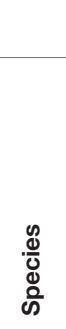 } & \multirow[b]{2}{*}{ 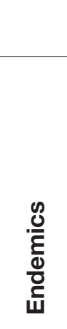 } & \multicolumn{3}{|c|}{ IUCN Status } & \multicolumn{9}{|c|}{ Reptiles Zones } \\
\hline & & & CR & EN & Vu & 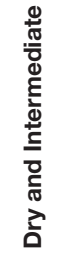 & 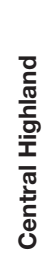 & 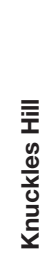 & $\begin{array}{l}+0 \\
3 \\
0 \\
0 \\
\frac{0}{3} \\
0\end{array}$ & 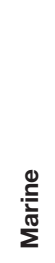 & 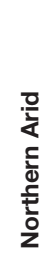 & 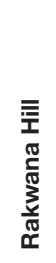 & 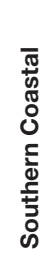 & 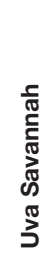 \\
\hline Crocodylidae & 2 & 0 & 0 & 1 & 0 & 2 & 0 & 0 & 0 & 0 & 2 & 0 & 2 & 1 \\
\hline Geoemydidae & 1 & 0 & 0 & 0 & 0 & 1 & 1 & 1 & 1 & 1 & 1 & 0 & 1 & 1 \\
\hline Cheloniidae & 4 & 0 & 0 & 4 & 0 & 0 & 0 & 0 & 0 & 4 & 0 & 0 & 0 & 0 \\
\hline Dermochelidae & 1 & 0 & 1 & 0 & 0 & 0 & 0 & 0 & 0 & 1 & 0 & 0 & 0 & 0 \\
\hline Testudinidae & 1 & 0 & 0 & 0 & 0 & 1 & 0 & 0 & 0 & 0 & 1 & 0 & 1 & 1 \\
\hline Gekkonidae & 62 & 52 & 24 & 14 & 9 & 20 & 15 & 10 & 16 & 8 & 7 & 10 & 9 & 12 \\
\hline Lacertidae & 2 & 0 & 0 & 0 & 0 & 2 & 0 & 0 & 0 & 0 & 2 & 0 & 0 & 2 \\
\hline Scincidae & 34 & 29 & 2 & 7 & 4 & 16 & 7 & 10 & 14 & 0 & 10 & 4 & 6 & 8 \\
\hline Varanidae & 2 & 0 & 0 & 0 & 0 & 2 & 1 & 2 & 2 & 0 & 2 & 1 & 2 & 2 \\
\hline Acrochordidae & 1 & 0 & 0 & 0 & 1 & 1 & 0 & 0 & 1 & 0 & 1 & 0 & 1 & 0 \\
\hline Erycidae & 1 & 0 & 0 & 0 & 0 & 1 & 0 & 0 & 0 & 0 & 1 & 0 & 1 & 1 \\
\hline Pythonidae & 1 & 0 & 0 & 0 & 0 & 1 & 1 & 1 & 1 & 0 & 1 & 1 & 1 & 1 \\
\hline Cylindrophiidae & 1 & 1 & 0 & 0 & 1 & 1 & 1 & 1 & 1 & 0 & 0 & 1 & 0 & 1 \\
\hline Colubridae & 47 & 26 & 3 & 7 & 8 & 29 & 25 & 26 & 31 & 0 & 15 & 18 & 19 & 24 \\
\hline Homalopsidae & 3 & 0 & 0 & 1 & 0 & 3 & 0 & 0 & 1 & 0 & 2 & 0 & 1 & 0 \\
\hline Elapidae & 20 & 2 & 0 & 1 & 0 & 4 & 3 & 3 & 2 & 15 & 3 & 2 & 3 & 3 \\
\hline
\end{tabular}

tropical species are likely to be more vulnerable to climatechange-induced temperature changes than more temperate species. A confirmatory example is provided by Sinervo et al. (2010), which showed in their recent surveys of 48 Mexican lizard species at 200 sites that $12 \%$ of local populations have gone extinct since 1975 , and by $208039 \%$ of local lizard populations and $20 \%$ of worldwide lizard species are predicted to go extinct due to climate change.

The capacity of reptiles to perform physiological and behavioral functions at different body temperatures is described by their thermal performance curve (Huey et al., 2012). It falls within critical limits (Araújo et al., 2006; Huey et al., 2009, 2012; Sinervo et al., 2010) and performance reaches a maximum within an optimal body temperature region. If their body temperature increases above the optimal body temperature then their performance drops rapidly. Body temperatures higher than the optima are known to create physiological stress, reduced performance and increased disease susceptibility, ultimately leading to population declines and extinctions (Root et al., 2003; Huey et al., 2010; Sinervo et al., 2010). Due to projected temperature increases of $1.1-6.4^{\circ} \mathrm{C}$ by the year 2100 , the metabolic rates of ectotherms could increase by $10-75 \%$ (Bickford et al., 2010). Such increases in metabolic rates, coupled with reduced foraging time, could be expected to negatively affect population growth rates (Bickford et al., 2010).

However, it is true that some reptiles do inhabit environments that are cooler than their optimum average temperatures (Deutsch et al., 2008), and they may actually benefit from rising temperatures (Araújo et al., 2006). For example, in common lizards, Lacerta vivipara positive correlations have been found between rising summer temperatures and body size, clutch size and total reproductive effort (Chamaillè-Jammes et al., 2006). In side-blotched lizards (Uta stansburiana) higher night-time temperatures increased reproductive success, hatchling size and hatchling survival (Clarke and Zani, 2012). Some species maybe able to buffer small temperature changes, but large temperature increases may force many species to shift their distributions to cooler climates. For example, open-habitat species may be forced 

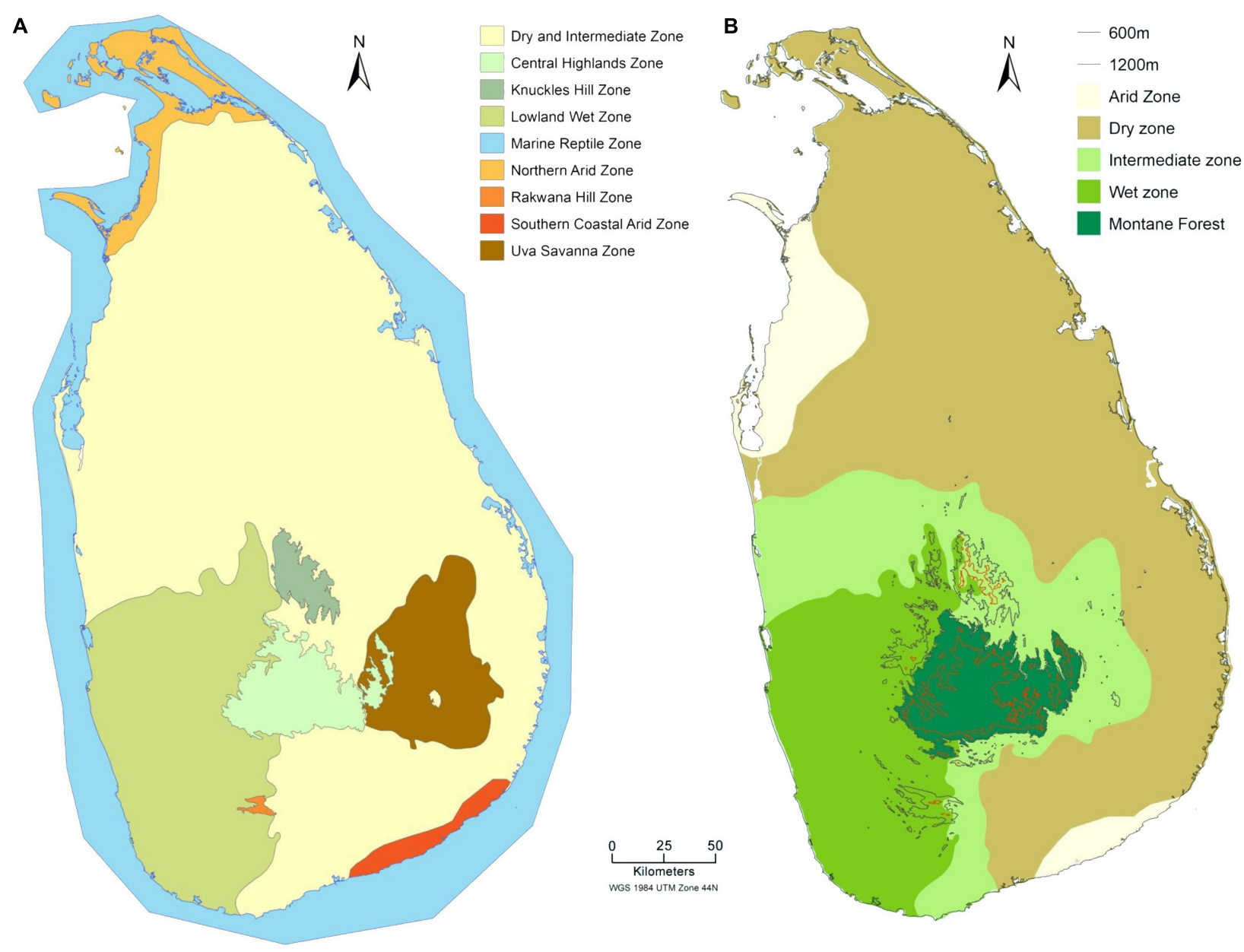

FIGURE 2 | Sri Lanka climatic zone maps. (A) Nine distinctive reptile zones (Ministry of Mahaweli Development and Environment, 2019) and (B) Five distinctive bioclimatic zones.

to invade closed forest environments (Huey et al., 2009). In Spain, changes in the distributions of reptiles were associated with increases in temperature, and 22 reptile species shifted pole-wards by an average of $15.2 \mathrm{~km}$ from 1940-1975 to 1991-2005, which is equivalent to approximately $0.5 \mathrm{~km} /$ year (Moreno-Rueda et al., 2012).

Nevertheless, many reptile species are unlikely to cope with changing climates because of habitat fragmentation and natural barriers to species movements. For example, in Europe $98 \%$ of reptiles may experience range contractions by 2050, if they have no dispersal capacity (Araújo et al., 2006). Furthermore, based on mean annual dispersal distance to favorable habitats under current conditions, future distribution (under climate change scenarios), it is predicted that up to $41 \%$ of the Australian arid zone gecko's (Gehyra variegata) current population would fail to colonize in their favorable microclimates by 2070 (Duckett et al., 2013).

With specific regard to Sri Lanka (also in tropical and subtropical regions) the degree of habitat fragmentation is much more severe in its southwestern region where much of the wilderness remains as forest fragments which are smaller than $100 \mathrm{~km}^{2}$, mainly due to infrastructure development, particularly road construction and industrial agriculture. In fact southwest Sri Lanka together with the Western Ghats of India is said to support the highest human population density among the world's biodiversity hotspots (Cincotta et al., 2000). If warming trends continue in tropical countries unabated, then the inhabitants of the lowland habitats will be forced to migrate to higher elevations in search of the optimal conditions. The lack of landscape-scale connectivity in southwestern Sri Lanka is expected to appreciably impede such species' movements.

The magnitude of the effects of warming on reptiles will depend on physiological and/or behavioral plasticity and their evolutionary adaptive capacities (Williams et al., 2008; Chevin et al., 2010; Hoffmann, 2010; Hoffmann et al., 2013; Monasterio et al., 2013). Most reptiles are able to control their body temperature precisely via behavioral and postural adjustments (Huey et al., 2003; Leal and Gunderson, 2012). Phenotypic plasticity is a significant factor in organisms in response to fluctuating environmental conditions (Walther et al., 2002; 
Parmesan and Yohe, 2003; Root et al., 2003; Berteaux et al., 2004). However, in organisms where changes in traits are simply a result of phenotypic plasticity, such changes occur much faster than evolutionary genetic changes, and are thus likely to have a more immediate and direct influence on responses to climate change (Williams et al., 2008; Chevin et al., 2010). Although behavioral thermoregulation is widespread in reptiles, unfortunately, so far we have a very limited understanding of how reptiles respond to temperature changes via evolutionary genetic changes.

Increased air temperature regimes are also expected to alter "reptiles" interactions with predators, with such changes being already evident. For example, they can be exposed to new predators when birds change their hunting grounds as a consequence of rising air temperatures (Low, 2007). Furthermore, brief exposure to temperatures above the critical thermal maximum $\left(\mathrm{CT}_{\max }\right)$ can cause the death of an individual which is unable to prevent its overheating; hatchlings will need to move between hotter and cooler surfaces more often, potentially exposing them to predators (Webb and Whiting, 2005) and lowering their chance of survival (Dayananda and Webb, 2017). Furthermore, high environmental temperatures may restrict an individual's ability to perform important activities such as foraging, defense or mating (Sinervo et al., 2010).

\section{Effects of Climate Warming During Embryonic Development}

In oviparous reptiles, temperature plays an important role during embryonic development and incubation temperature can affect the offspring in a variety of ways (Angilletta, 2009). Increases in air temperatures cause higher temperatures inside lizard nests (Dayananda et al., 2016) and recent research has predicted significant declines in lizard populations over the next century (Sinervo et al., 2010). Thus, one of the most significant impacts of climate change on reptiles is expected to be derived from the effects of warming during their embryonic development.

The effect of the thermal environment during embryonic development has been examined in a wide variety of reptilian taxa. For example, laboratory studies indicate that in oviparous reptiles, incubation temperature directly affects a range of factors, including the duration of incubation, embryo survival and the size, shape, behavior, sex, and performance of hatchlings (Janzen, 1994; Downes and Shine, 1999; Du and Ji, 2003; Deeming, 2004; Parker and Andrews, 2007). These experimental information can be integrated into forecasts of species survival and geographical distribution under projected climate warming regimes.

However, these effects appear to vary between species. For example, in wall lizards (Podarcis muralis) higher incubation temperatures produced smaller and lighter hatchlings which ran more slowly than hatchlings from eggs that were incubated at cooler temperatures (Brana and Ji, 2000). In general, hotter incubation temperatures increase locomotor performance in some turtles and lizards (but not in others-see Booth et al., 2000) and increases in locomotor performance would generally be expected to increase the ability of hatchlings to escape from predators (Janzen, 1993). For example, in chelonians, increases in incubation temperature increased the swimming performance and body size of Apalone mutica (Janzen, 1993); similarly, in Pelodiscus sinensis (Du and Ji, 2003) and Chelonia mydas (Booth et al., 2004), Saproscincus mustelina, Lampropholis delicata (Downes and Shine, 1999) but also actual decreases in P. muralis (Van Damme et al., 1992), Nannoscincus maccoyi (Downes and Shine, 1999), Takydromus wolteri (Chen et al., 2003), and Takydromus septentrionalis (Du and Ji, 2006).

Incubation temperature can also influence the growth rate of hatchling reptiles. There is a general trend for post-hatching growth rates to increase at higher incubation temperatures (Hutton, 1987; Webb and Cooper-Preston, 1989; Spotila et al., 1994; Roosenburg and Kelley, 1996; Demuth, 2001; Ji et al., 2003; Booth et al., 2004; Nelson et al., 2004; Andrews, 2008).

The gender of oviparous reptiles is determined by the environmental temperature during incubation and cannot be predicted by zygotic genotype [temperature-dependent sex determination (TSD)]. The following three patterns of TSD can be observed in reptiles: (a) species with TSD Ia [malefemale (MF)] produce males at low temperatures and females at high temperatures; (b) species with TSD Ib [female-male (FM)] produce females at low temperatures and males at high temperatures, and (c) species with TSD II [female-male-female (FMF)] produce females at low and high temperatures and males at intermediate temperatures. TSD Ia has been reported for turtles, TSD Ib for tuatara, lizards and crocodilians and TSD II for turtles, lizards, and crocodilians (Valenzuela, 2004). Therefore, changes in the climate are expected to result in appreciable differences in the hatchling sex ratio, which can then alter the operational sex ratio. In the longer term, these trends can result in dramatic changes in the population sex ratio and can ultimately drive a population to become either male or female limited. Such changes can consequently have negative impacts on mate selection strategies. Cumulatively, these impacts are expected to lead to reduced recruitments in the population, gradually leading to declining numbers.

However, this picture is complicated as it is not entirely clear that all reptiles possess TSD and additionally, TSD and GSD are not necessarily mutually exclusive (Holleley et al., 2015). For example, incubation temperature does not affect the sex ratio of the Chinese soft-shelled turtle P. sinensis (Ji et al., 2003), and the Brisbane river turtle Emydura signata also possesses GSD (Booth et al., 2004). In essence, TSD has been found in all crocodilians, tuatara, and it is prevalent in the turtles but less frequent in lizards (Valenzuela, 2001, 2004; Nelson et al., 2004). Furthermore, TSD differs in occurrence between families of reptiles. For example, many turtles exhibit TSD, whereas no example has been reported from the families Trionychilidae and Chelidae. In lizards, TSD is common in the Agamidae and Gekkonidae, but reports are absent for the Teiidae, Phrynosomatidae, and Polychrotidae (Valenzuela, 2004). Theoretically, TSD species with larger clutches deposit their eggs at various depths in the nest and eggs at the top are exposed to the high temperature than those at the bottom of the nest; hence, these more prolific species will have different sex ratios within the same nest (Georges et al., 2004).

Incubation temperature is also known to affect the "lizards" behavior and survival. For example, larger side-blotched lizards (U. stansburiana) and tree lizard (Urosaurus ornatus) hatchlings 
had a higher probability of survival compared to their smaller counterparts (Ferguson and Fox, 1984; Miles, 2004) and higher incubation temperatures decrease the survival of the velvet gecko (Dayananda et al., 2016). Furthermore, at higher temperatures Yucatan banded geckos (Coleonyx elegans) were less active than individuals from low incubation temperature regimes, in relation to their anti-predator behaviors (Trnik et al., 2011). Learning ability of hatchlings has also been demonstrated to be affected by incubation temperature; in Velvet gecko (Amalosia lesueurii) eggs incubated at elevated temperatures hatchlings showed reduced learning abilities and associated lower survival rates in the wild (Dayananda and Webb, 2017; Dayananda et al., 2017b).

Also, a strong link has been established between incubation temperature and the critical thermal tolerance limits in hatchlings of the velvet gecko. Hatchlings from high-temperature incubators had a lower critical thermal maximum $\left(38.7^{\circ} \mathrm{C}\right)$ and a higher critical thermal minimum $\left(6.2^{\circ} \mathrm{C}\right)$ compared to hatchlings from cold-temperature incubators (Dayananda et al., 2017a). Decreased thermal tolerance may also reduce the time available for hatchlings to forage by forcing them to remain inside shelters for longer periods and also species living in thermally stressful environments at high environmental temperatures can force body temperatures to reach the critical thermal maximum (Sinervo et al., 2010).

\section{Effects of Sea Level and Temperature Increase on Aquatic Reptiles}

Water temperature is one of the most important factors which directly affects fitness, reproductive traits and geographical distributions of aquatic reptiles (Elsworth et al., 2003; Pike et al., 2006; Mazaris et al., 2008). For example, water temperature has been correlated with nesting dates in Loggerhead Sea turtle Caretta caretta, and the extent of its nesting season decreased by about 43 days due to warmer sea surface temperatures (Pike et al., 2006). Furthermore, over the last 17 years, leatherback turtle (Dermochelys coriacea) populations in the North Atlantic have moved their northern boundary distribution by $330 \mathrm{~km}$ (McMahon and Hays, 2006).

The geographical distributions of aquatic reptile also clearly depend on the availability of their prey and changes to their foraging areas and availabilities of food resources can also be dependent on rising water temperatures/mean annual sea surface temperature (Witt et al., 2007). For example, redistribution or/and decreasing prey populations has affected (a) the growth and reproductive output and also the duration of the interval between breeding seasons in Green turtles (C. mydas) (Broderick et al., 2003), and (b) the nesting abundance of Loggerhead turtle (C. caretta) (Chaloupka et al., 2008).

Similar observations have also been made in freshwater reptiles. For instance, semi-aquatic snakes such as Garter snakes and water snakes tend to shift their foraging grounds as the seasons progresses (Southwood and Avens, 2010). With the predicted climate change, the seasonal shifts can become more abrupt and the length of the growing season can also change. These climatic modification can be expected to also impact the life histories of reptilian prey, and thereby, will induce changes in both spatial and temporal distribution of suitable foraging grounds.

Sea levels are projected to rise by a further $0.5-2.0 \mathrm{~m}$ by 2100 (Nicholls et al., 2011) with a current mean sea level rise of $3.6 \mathrm{~mm}$ year $^{-1}$ (IPCC, 2019) which directly links with the global temperature increment of increase (Vermeer and Rahmstorf, 2009). Rising sea levels have already led to the intrusion of saltwater upstream, increasing the salinity of freshwater wetlands in Northern Australia (Mulrennan and Woodroffe, 1998), and this effect will continue to negatively impact the freshwater reptiles in many regions as sea levels continue to rise. For example, the Roti Island snake-necked turtle (Chelodina mccordi) has been predicted to disappear due to rising water levels on the low-lying islands this species inhabits (Bickford et al., 2010). Increasing salinity in freshwater habitats has already influenced the distribution of the American alligator (Alligator mississippiensis) and has led to reduced growth rates and survival in the American crocodile (Crocodylus acutus) (Mazzotti and Brandt, 1994; Mazaris et al., 2009). Furthermore, increasing salinity in freshwater habitats in Southern Sri Lanka has already influenced the Estuarine crocodile (C. porosus) in its distribution, population reductions and increased level of human-crocodile conflict (Amarasinghe et al., 2015). Rising sea levels also threaten other coastal and brackish-water habitats such as sand dunes, coastal grasslands and scrublands, and tidal marshes. Reptiles specialized for these unique ecosystems (e.g., Diamond-backed terrapins) may also lose their critical habitats due to rising sea levels (Bickford et al., 2010).

With specific reference to Sri Lanka there are five species of marine turtles that employ its coastal zone for nesting. Among them, Leatherback Turtle (D. coriacea), Loggerhead Turtle (C. caretta), and Olive Ridley Turtle (Lepidochelys olivacea) are already classified as Vulnerable and the Green Turtle (C. mydas) is classified as Endangered. The Hawksbill Turtle (Eretmochelys imbricata) is classified as Critically Endangered but how rising sea levels may affect them has not been ascertained to date (Supplementary Table 1 highlighting all reptile families and species in Sri Lanka with their geographical distributional zones and IUCN Red List status). However, in the Caribbean islands up to $32 \%$ of the total current beach area which is important nesting ground for both Hawksbill (E. imbricata) and Loggerhead (C. caretta) turtles could be lost if sea levels rise by $0.5 \mathrm{~m}$ (Fish et al., 2005). It is also predicted that in the northwestern Hawaiian islands up to $40 \%$ of the Green turtle's (C. mydas) nesting beaches could be lost following a $0.9 \mathrm{~m}$ sea level rise (Baker et al., 2006). In the northern Great Barrier Reef in Australia up to $38 \%$ of available nesting area will be lost by the largest green turtle population in the World due to the projected sea-level rises (Fuentes et al., 2010). Generally, rising sea level predominantly affects the availability of nesting sites for sea turtles, with females needing to find alternative nesting sites along neighboring coastlines. Coastal erosion may limit the number of alternative nesting sites with the outcome of several females choosing the same location which is similar to a communal nesting behavior. This higher nest density can increase the risk of nest destruction by other nesting females which also leads to the increasing embryo mortality and reduced overall reproductive success 
(Mazaris et al., 2009; Fuentes et al., 2010). Thus it is clear from these international studies that all marine turtles in Sri Lanka are potentially vulnerable to rising sea levels and that increased coastal erosion may significantly reduce their nest sites, increase embryonic mortality and thereby reduce their reproductive success, ultimately causing their populations to decline.

Moreover, reptilian pathogen densities, distributions and population dynamics can be indirectly influenced by the environmental factors mediated by climate disruption. For example, due to enhanced rainfall, two tick species Aponomma hydrosauri and Amblyomma limbatum have changed their boundary positions and the density of ticks on lizards in regions flanking the boundary zone has increased for A. hydrosauri and decreased for A. limbatum (Bull and Burzacott, 2001).

\section{REPTILIAN BIODIVERSITY RESEARCH GAPS AND FUTURE REQUIREMENTS IN SRI LANKA UNDER CLIMATE CHANGE}

Human-induced pressures on national biodiversity continue unabated, and it is increasingly important that conservation efforts are prioritized to maximize conservation returns in a world of limited human and financial resources. As such, conservation scientists continue to evaluate the vulnerability of organisms to climate change to support the implementation of evidence-based management strategies to mitigate the impacts of climate change in order to conserve threatened species (Lee and Jetz, 2008).

By assessing the biodiversity impacts of both state and nonstate actors, we can identify their contributions to biodiversity conservation efforts (Mair et al., 2021). However, the assessment of a species' response to ongoing climate warming, and the conservation actions required to mitigate the impacts, are among the most significant and controversial challenges for ecologists in the future. Specifically, efficient conservation planning and the desired actions needed to abate threats to species loss is hampered by key biodiversity knowledge gaps (Hoveka et al., 2020). For reptiles in particular, to better predict which species are at risk, accurate data is are required on species' exposure to thermal stressors in the environment, their sensitivity to such stressors, and their ability to adapt to such stressors (Williams et al., 2008).

This is especially true for the Indian Oceanic tropical island nation of Sri Lanka, where gaps in our knowledge of species distribution under current and future climate change scenarios are still limited. To avert the impacts of climate change on this rich reptilian fauna requires a collaborative effort of government working closely with civil society and local communities to ensure that biodiversity is properly conserved and sustainably utilized. To achieve this, we propose that targeted conservation actions for Sri Lankan reptiles under the climate change scenarios should be geared toward identifying Environmentally Sensitive Areas (ESA), in order to conserve significant Sri Lankan ecosystems that are outside protected areas and using reptiles as an indicator taxon. This can be achieved by conducting research studies on climate change impacts on ecosystems and reptiles, e.g., (a) identification of indicator species for long term population monitoring and research priorities, (b) modeling impacts of climate change on reptiles, their changing distribution patterns, and boundary shifts of climatic zones, (c) lifecycle studies on their sex ratios, and (d) ex situ conservation) (Figure 2). Additionally, an enhanced reptile protection can be achieved by developing mechanisms to establish and improve the skills of conservationist throughout the country and by partnering with local communities in sustainable management strategies in the agriculture and tourism sectors of the economy. Addressing the insufficient level of protection for reptiles will represent a significant contribution toward tackling the Leopoldean shortfall in Sri Lanka (see Hoveka et al., 2020 for further details). Key research gaps that need to be prioritized include those described below.

\section{Tracking Shifts in Species Distribution Under Climate Change Scenarios}

Environmental niche models (ENMs) have become popular tools for forecasting the potential impacts of future climate change on the geographical distributions of species (Sillero, 2011). These models are used first to analyze the geographic distribution of a species' niche resulting from existing climatic conditions and then to generate projections of future range shifts under climate change. This is achieved by correlating the records of a "species" occurrences with a set of environmental variables under a range of climate change scenarios (Araújo and Pearson, 2005; Bezeng et al., 2017).

The main advantages of ENMs are their relatively low data requirements and capacity for rapid analysis, which can provide the baseline information on the status of species that may require immediate e conservation actions. Thus ENMs have been used to assess species vulnerability to climate change across numerous taxonomic groups, and in many regions of the world (Araújo and Luoto, 2007).

Current and future climate data, including 19 Bioclimatic variables layers, is available for such ENM modeling in various databases such as WorldClim (Fick and Hijmans, 2017). Unfortunately, in Sri Lanka the availability of "species" occurrences (i.e., presence/absence) data is not publicly available for research due to personnel authorships and access restrictions by the relevant governmental organizations which are responsible for the preparation of the IUCN Red List. Due to these constraints on data access, ENMs are still new to tropical countries and are yet to be employed in order to investigate the impact of climate change on organisms, especially ectotherms (but see Bezeng et al., 2017). Additionally, ENM approaches are still limited in handling other forms of species data (e.g., life history traits), which are fundamental to enhancing the predictive accuracy (but see Huang et al., 2020). Amidst these challenges, ENMs hold huge potential as a conservation tool for wildlife management in tropical regions (see review by Cayuela et al., 2009 and references therein). Specifically, many megadiverse countries in Latin American have successfully used ENM approaches to model the range shifts of various species across different biogeographic realms in order to identify pre-emptive conservation management strategies to avoid extinction from 
climate related causes (Urbina-Cardona et al., 2019). Particularly, the adoption of ENM approaches that incorporate both climate and eco-physiological data for reptiles (as shown in section "Climate Change Impacts on the Eco-physiology of Reptiles") will help improve prediction of a species' potential for range shifts under climate change scenarios. The obvious first step that Sri Lankan researchers could take is to establish an open access biodiversity and species occurrence data repository. One regional example for consideration in tropical and subtropical countries is the Atlas of Living Australia ${ }^{1}$, which provides biodiversity data from multiple sources and makes it freely available online for all researchers to use in their investigations.

\section{Physiological Sensitivity of Adults to Elevated Temperatures}

The increases in environmental temperature are the most direct outcome of climate change. It is well established that such increases alter body temperature of reptiles and consequently their physiological performance and vulnerability (Huey et al., 2012). The complete thermal performance or fitness curve of an organism provides robust understanding of their sensitivity and response to temperature. Thus measurement of the temperature at which performance is maximized (Topt), the critical thermal maximum $\left(\mathrm{CT}_{\max }\right)$ and the critical thermal minimum $\left(\mathrm{CT}_{\min }\right)$ values provide critical information on how tropical and subtropical reptiles will respond to increased environmental temperature and allows assessment of their physiological consequences. The thermal tolerance limits $\mathrm{CT}_{\max }$ and $\mathrm{CT}_{\min }$ constitute the endpoints of thermal performance curves which are generally associated with loss of the righting response (LRR) (Lutterschmidt and Hutchison, 1997a). It provides critically important information on how an organism's physiology, distribution and ecology are influenced by climate (Lutterschmidt and Hutchison, 1997b).

Performance curves illustrate the ability of reptiles to perform a specific activity at different body temperatures (Huey et al., 2012). Common traits for performance curves include locomotor speed, endurance, prey capture ability, development time, reproductive rate, growth rate, and net energy gain (Huey and Stevenson, 1979; Hertz et al., 1988; Huey et al., 1990, 2012; Angilletta et al., 2002). Among these traits, locomotion is the most frequently measured indicator of performance (Waldschmidt and Tracy, 1983; Huey and Kingsolver, 1989; Rall and Woledge, 1990; Adolph and Porter, 1993; Swoap et al., 1993; Hawkins, 1995; Kubisch et al., 2011; Woolrich-Piña et al., 2012; Aidam et al., 2013). Studies on lizards suggest that locomotor performance, which is tightly linked to an individual's body temperature, influences fitness (Irschick and Garland, 2001). Thus, analysis of reptile performance is a useful proxy for studying their relationship between environmental temperature, physiological adaptations, their ecological relevance and relates to their evolutionary traits (Huey and Stevenson, 1979; Huey and Bennett, 1987; Huey and Kingsolver, 1989). Lizards living in lowland forests and open habitats are at high risk from climate warming and they are already experiencing body temperature

${ }^{1}$ www.ala.org.au/ at or above their optimal body temperature (Huey et al., 2009). Hence, performance experiments on tropical lizards, particularly those living in the dry zone (see Figure 2) and also along the latitudinal gradient is highly desirable to understand their current physiological adaptations for the following reasons:

(i) There are no studies to date on reptile performance so far conducted with Sri Lankan species which would inform on their thermal requirements and behavioral thermoregulation capacities;

(ii) Although Sri Lanka publishes consecutive national Red Lists, the impacts of climate change on species is not well-considered or evaluated (see Foden et al., 2008). For example, the ability of IUCN criteria to detect risks imposed by potentially slow-acting threats such as climate change is very limited as a criterion to detect rates of population decline over periods of 5 years.

(iii) As it is well documented that tropical lizards are highly vulnerable to climate change (Huey et al., 2009; Sinervo et al., 2010), it is imperative that the most threatened reptile taxa in Sri Lanka are identified in order to establish sciencebased conservation initiatives and management actions before populations go locally extinct.

\section{Physiological Sensitivity of Embryos to Elevated Temperatures}

Climate warming is also predicted to cause higher temperatures inside reptilian nests (Dayananda et al., 2016). Predicting the vulnerability of oviparous reptiles to climate warming therefore, also requires knowledge of how increases in incubation temperature affect sensitive life stages, particularly embryos (Booth et al., 2000; Valenzuela, 2001; Huey et al., 2012; Urban et al., 2014). Thermal environments during embryonic development have been examined in a wide variety of reptilian taxa, and incubation experiments suggest that incubation temperatures are able to affect incubation length as well as embryo survival, size, shape, behavior and sex, and the performance of hatchlings (Deeming, 2004). Additionally, thermal sensitivity of oviparous embryos depends on their upper thermal limits, and increased thermal stress beyond these upper limits will lead to cardiac arrest of embryos (Angilletta et al., 2013). Therefore, we propose the following two steps to better predict the physiological sensitivity of reptilian embryos under climate change scenarios;

(a) An understanding is required of the correlation between nest temperature and environmental temperature, particularly for species which lay their eggs in open nests, inside crevices or underneath rocks and which lay their eggs communally (e.g., Calodactylodes illingworthorum and Cnemaspis species). These eggs are particularly vulnerable to heatwaves that are predicted to increase in frequency and duration in future. Strong positive linear correlation between air temperatures and nest temperatures demonstrate that those hotter air temperatures will produce hotter nests in the future (Dayananda et al., 2016).

(b) Programmable incubators to be employed that can be set at natural nest temperatures and the predicted future nest 
temperatures, to incubate lizard eggs in order to measure and compare morphology, physiology, performance and sex of resulting hatchlings.

(c) Investigations of the physiological and biochemical adaptations of embryos leading to their heat tolerance by analysis of heat shock proteins (HSPs), particularly HSP70. It is well known that HSPs are upregulated when organisms are exposed to extreme temperatures (Feder and Hofmann, 1999; Sørensen, 2010). However, production of HSPs reduce the rates of synthesis of other proteins and can lead to decreasing fecundity, developmental and survival rates of hatchlings (Feder and Hofmann, 1999). For example, high incubation temperatures associated with overexpression of HSP70 during embryonic development of hatchling turtles led to their decreased heat tolerance (Gao et al., 2014).

\section{Maternal Sensitivity and Responses to Climate Change}

Gravid female reptiles can protect their embryos against the higher nest temperatures by laying eggs earlier, digging deeper nests, or choosing cooler/shadier nest sites (Doody et al., 2006). Information is required on how gravid females actually do respond to higher environmental temperatures during their nesting period and also their plasticity in nesting behaviors. In particular, these studies are important for marine turtles and dry zone lizards because they are already identified as the most vulnerable groups in the future (Figure 2).

\section{CONCLUDING REMARKS}

Based on the eco-physiological studies which have already been conducted in other parts of the world, it is reasonable to assume that tropical reptiles will face a range of detrimental effects of climate change with declining population sizes, and altered community structures and ultimately extinctions. Thus, particularly for Sri Lanka, we need to establish and conduct a set of comprehensive studies to explore how future climate change is most likely to affect the persistence of reptiles, given the current deficit of information required to predict speciesspecific vulnerabilities to climate change. Furthermore, longerterm studies are also necessary to determine whether warming will contribute to local extinctions, as has occurred elsewhere (Sinervo et al., 2010). This recommended research program will accordingly increase our understanding of the potential impacts

\section{REFERENCES}

Ackerman, R. A. (1980). Physiological and ecological aspects of gas exchange by sea turtle eggs. Am. Zool. 20, 575-583. doi: 10.1093/icb/20.3. 575

Ackerman, R. A. (1991). "Physical factors affecting the water exchange of buried reptile eggs," in Egg Incubation: Its Effects on Embryonic Development in Birds and Reptiles, eds D. C. Deeming and M. W. J. Ferguson (Cambridge: Cambridge University Press).

Adolph, S. C., and Porter, W. P. (1993). Temperature, activity, and lizard life histories. Am. Nat. 142, 273-295. doi: 10.1086/285538 of climate change on tropical reptiles and benefit Conservation Biologists by the provision of data that is necessary to both model and mitigate the impacts of climate change on reptiles. Documentation of the contemporary status of reptilian taxa based on IUCN Red List standard has continued for more than 20 years in Sri Lanka. However, the applied research and experimentation on the probable effects of climate change have not been achieved to date. The evidence to predict threatened reptile species and their responses to environmental change is still not available. Thus it is crucial that such research is conducted to identify the taxa most vulnerable to climate change, in order to reduce the likelihood that they may go extinct, and so that society continues to benefit from the many ecosystem services provided by reptiles.

\section{AUTHOR CONTRIBUTIONS}

$\mathrm{BD}$ conceived and designed the project. $\mathrm{BD}, \mathrm{SB}, \mathrm{SK}$, and $\mathrm{RJ}$ wrote the manuscript. All authors contributed to the article and approved the submitted version.

\section{ACKNOWLEDGMENTS}

SK would like to extend his sincere gratitude to Suranjan Fernando, Buddhika Madurapperuma, Anslem de Silva, Kanishka Ukuwela, Thasun Amarasinghe, Thilina Surasinghe, and Lankani Somarathna for various help with field surveys, and help with reptile zone maps. The Department of Wildlife, and Forest Conservation Department for research permission. Finally, we would like to thank two reviewers and the Associate Editor for constructive comments that have helped improve the earlier version of this manuscript.

\section{SUPPLEMENTARY MATERIAL}

The Supplementary Material for this article can be found online at: https://www.frontiersin.org/articles/10.3389/fevo.2021. 688723/full\#supplementary-material

Supplementary Table 1 | Reptile families and species in Sri Lanka with their geographical distributional zones (please refer to the reptile zones map in Figure 2A), and current conservation status (After Ministry of Mahaweli Development and Environment, 2019; Gibson et al., 2020).

Aidam, A., Michel, C. L., and Bonnet, X. (2013). Effect of ambient temperature in neonate aspic vipers: growth, locomotor performance and defensive behaviors. J. Exp. Zool. Part A: Ecol. Genet. Physiol. 319, 310-318. doi: 10.1002/jez.1 794

Amarasinghe, T., Madawala, M., Karunarathna, S., Manolis, C., de Silva, A., and Sommerlad, R. (2015). Human-crocodile conflict \& conservation implications of Saltwater Crocodiles Crocodylus porosus (Reptilia: Crocodylia: Crocodylidae) in Sri Lanka. J. Threatened Taxa 7, 7111-7130.

Andrews, R. M. (2008). Effects of incubation temperature on growth and performance of the veiled chameleon (Chamaeleo calyptratus). J. Exp. Zool. Part A: Ecol. Genet. Physiol. 309, 435-446. doi: 10.1002/jez.470 
Angilletta, M. J. (2009). Thermal Adaptation: a Theoretical and Empirical Synthesis. Oxford: Oxford University Press.

Angilletta, M. J., Zelic, M. H., Adrian, G. J., Hurliman, A. M., and Smith, C. D. (2013). Heat tolerance during embryonic development has not diverged among populations of a widespread species (Sceloporus undulatus). Conserv. Physiol. 1:cot018. doi: 10.1093/conphys/cot018

Angilletta, M. J. J., Hill, T., and Robson, M. A. (2002). Is physiological performance optimized by thermoregulatory behavior? a case study of the eastern fence lizard, Sceloporus undulatus. J. Thermal Biol. 27, 199-204. doi: 10.1016/s03064565(01)00084-5

Araújo, M. B., and Luoto, M. (2007). The importance of biotic interactions for modelling species distributions under climate change. Global Ecol. Biogeography 16, 743-753. doi: $10.1111 / j .1466-8238.2007 .00359 . x$

Araújo, M. B., and Pearson, R. G. (2005). Equilibrium of 'species' distributions with climate. Ecography 28, 693-695. doi: 10.1111/j.2005.0906-7590.04253.x

Araújo, M. B., Thuiller, W., and Pearson, R. G. (2006). Climate warming and the decline of amphibians and reptiles in Europe. J. Biogeography 33, 1712-1728. doi: 10.1111/j.1365-2699.2006.01482.x

Baker, J. D., Littnan, C. L., and Johnston, D. W. (2006). Potential effects of sea level rise on the terrestrial habitats of endangered and endemic megafauna in the Northwestern Hawaiian Islands. Endangered Species Res. 2, 21-30. doi: 10.3354/esr002021

Belinsky, A., Ackerman, R., Dmi'el, R., and Ar, A. (2004). "Water in reptilian eggs and hatchlings," in Reptilian Incubation: Environment, Evolution and Behaviour, ed. D. C. Deeming (Nottingham: Nottingham University Press), 125-141.

Bellard, C., Bertelsmeier, C., Leadley, P., Thuiller, W., and Courchamp, F. (2012). Impacts of climate change on the future of biodiversity. Ecol. Lett. 15, 365-377. doi: 10.1111/j.1461-0248.2011.01736.x

Berteaux, D., Réale, D., McAdam, A. G., and Boutin, S. (2004). Keeping pace with fast climate change: can arctic life count on evolution? Int. Comp. Biol. 44, 140-151. doi: 10.1093/icb/44.2.140

Bezeng, B. S., Tesfamichael, S. G., and Dayananda, B. (2017). Predicting the effect of climate change on a range-restricted lizard in southeastern Australia. Curr. Zool. 64, 165-171. doi: 10.1093/cz/zox021

Bickford, D., Howard, S. D., Ng, D. J., and Sheridan, J. A. (2010). Impacts of climate change on the amphibians and reptiles of Southeast Asia. Biodiversity Conserv. 19, 1043-1062. doi: 10.1007/s10531-010-9782-4

Booth, D., Thompson, M., and Herring, S. (2000). How incubation temperature influences the physiology and growth of embryonic lizards. J. Comp. Physiol. B 170, 269-276. doi: 10.1007/s003600000097

Booth, D. T., Burgess, E., McCosker, J., and Lanyon, J. M. (2004). "The influence of incubation temperature on post-hatching fitness characteristics of turtles," in Proceedings of the International Congress Series, (Amsterdam: Elsevier).

Brana, F., and Ji, X. (2000). Influence of incubation temperature on morphology, locomotor performance, and early growth of hatchling wall lizards (Podarcis muralis). J. Exp. Zool. 286, 422-433. doi: 10.1002/(sici)1097-010x(20000301) 286:4<422::aid-jez10>3.0.co;2-d

Broderick, A. C., Glen, F., Godley, B. J., and Hays, G. C. (2003). Variation in reproductive output of marine turtles. J. Exp. Mar. Biol. Ecol. 288, 95-109. doi: 10.1016/s0022-0981(03)00003-0

Brondizio, E., Settele, J., Díaz, S., and Ngo, H. T. (2019). Global Assessment Report on Biodiversity and Ecosystem Services of the Intergovernmental Science-Policy Platform on Biodiversity and Ecosystem Services. Bonn: IPBES.

Bull, C. M., and Burzacott, D. (2001). Temporal and spatial dynamics of a parapatric boundary between two Australian reptile ticks. Mol. Ecol. 10, 639648. doi: 10.1046/j.1365-294x.2001.01214.x

Burt, T., and Weerasinghe, K. (2014). Rainfall distributions in Sri Lanka in time and space: an analysis based on daily rainfall data. Climate 2, 242-263. doi: 10.3390/cli2040242

Cayuela, L., Golicher, D. J., Newton, A. C., Kolb, M., de Alburquerque, F. S., et al. (2009). Species distribution modeling in the tropics: problems, potentialities, and the role of biological data for effective species conservation. Trop. Conserv. Sci. 2, 319-352. doi: 10.1177/194008290900200304

Chaloupka, M., Kamezaki, N., and Limpus, C. (2008). Is climate change affecting the population dynamics of the endangered Pacific loggerhead sea turtle? J. Exp. Mar. Biol. Ecol. 356, 136-143. doi: 10.1016/j.jembe.2007.12.009

Chamaillè-Jammes, S., Massot, M., Aragon, P., and Clobert, J. (2006). Global warming and positive fitness response in mountain populations of common lizards Lacerta vivipara. Global Change Biol. 12, 392-402. doi: 10.1111/j.13652486.2005.01088.x

Chen, X.-J., Xu, X.-F., and Ji, X. (2003). Influence of body temperature on food assimilation and locomotor performance in white-striped grass lizards, Takydromus wolteri (Lacertidae). J. Thermal Biol. 28, 385-391. doi: 10.1016/ s0306-4565(03)00022-6

Chevin, L.-M., Lande, R., and Mace, G. M. (2010). Adaptation, plasticity, and extinction in a changing environment: towards a predictive theory. PLoS Biol. 8:e1000357. doi: 10.1371/journal.pbio.1000357

Cincotta, R. P., Wisnewski, J., and Engelman, R. (2000). Human populations in the biodiversity hotspots. Nature 404, 990-992.

Clarke, D. N., and Zani, P. A. (2012). Effects of night-time warming on temperate ectotherm reproduction: potential fitness benefits of climate change for sideblotched lizards. J. Exp. Biol. 215, 1117-1127. doi: 10.1242/jeb065359

Day, O. (2009). The Impacts of Climate Change on Biodiversity in Caribbean Islands: what we know, what we need to know, and Building Capacity for Effective Adaptation. Trinidad and Tobago: Caribbean Natural Resources Institute.

Dayananda, B., Gray, S., Pike, D., and Webb, J. K. (2016). Communal nesting under climate change: fitness consequences of higher nest temperatures for a nocturnal lizard. Global Change Biol. 22, 2405-2414. doi: 10.1111/gcb.13 231

Dayananda, B., Murray, B. R., and Webb, J. K. (2017a). Hotter nests produce hatchling lizards with lower thermal tolerance. J. Exp. Biol. 220, 2159-2165. doi: $10.1242 /$ jeb.152272

Dayananda, B., Penfold, S., and Webb, J. (2017b). The effects of incubation temperature on locomotor performance, growth and survival in hatchling velvet geckos. J. Zool. 303, 46-53. doi: 10.1111/jzo.12460

Dayananda, B., and Webb, J. K. (2017). Incubation under climate warming affects learning ability and survival in hatchling lizards. Biol, Lett. 13:20170002. doi: 10.1098/rsbl.2017.0002

de Silva, A., and Ukuwela, K. (2017). A 'Naturalist's Guide to the Reptiles of Sri Lanka. Oxford: John Beaufoy Publishing Ltd, 176.

Deeming, D. C. (2004). "Post-hatching phenotypic effects of incubation in reptiles," in Reptilian Incubation: Environment, Evolution and Behaviour, ed. D. C. Deeming (Nottingham: Nottingham University Press).

Demuth, J. P. (2001). The effects of constant and fluctuating incubation temperatures on sex determination, growth, and performance in the tortoise Gopherus polyphemus. Can. J. Zool. 79, 1609-1620. doi: 10.1139/z01-120

Deutsch, C. A., Tewksbury, J. J., Huey, R. B., Sheldon, K. S., Ghalambor, C. K., Haak, D. C., et al. (2008). Impacts of climate warming on terrestrial ectotherms across latitude. Proc. Natl. Acad. Sci. U S A. 105, 6668-6672. doi: 10.1073/pnas. 0709472105

Doody, J. S., Guarino, E., Georges, A., Corey, B., Murray, G., and Ewert, M. (2006). Nest site choice compensates for climate effects on sex ratios in a lizard with environmental sex determination. Evol. Ecol. 20, 307-330. doi: 10.1007/s10682006-0003-2

Downes, S. J., and Shine, R. (1999). Do incubation-induced changes in a lizard's phenotype influence its vulnerability to predators? Oecologia 120, 9-18. doi: $10.1007 / \mathrm{s} 004420050827$

Du, W. G., and Ji, X. (2003). The effects of incubation thermal environments on size, locomotor performance and early growth of hatchling soft-shelled turtles Pelodiscus sinensis. J. Thermal Biol. 28, 279-286. doi: 10.1016/s0306-4565(03) 00003-2

Du, W. G., and Ji, X. (2006). Effects of constant and fluctuating temperatures on egg survival and hatchling traits in the northern grass lizard (Takydromus septentrionalis, Lacertidae). J. Exp. Zool. Part A: Comp. Exp. Biol. 305, 47-54. doi: $10.1002 /$ jez.a.243

Duckett, P. E., Wilson, P. D., and Stow, A. J. (2013). Keeping up with the neighbours: using a genetic measurement of dispersal and species distribution modelling to assess the impact of climate change on an Australian arid zone gecko (Gehyra variegata). Diversity Distribut. 19, 964-976. doi: 10.1111/ddi. 12071

Elsworth, P. G., Seebacher, F., and Franklin, C. E. (2003). Sustained swimming performance in crocodiles (Crocodylus porosus): effects of body size and temperature. J. Herpetol. 37, 363-368. doi: 10.1670/0022-1511(2003)037[0363: sspicc]2.0.co;2

Evans, G. W. (2019). Projected behavioral impacts of global climate change. Annu. Rev. Psychol. 70, 449-474. doi: 10.1146/annurev-psych-010418-103023 
Feder, M. E., and Hofmann, G. E. (1999). Heat-shock proteins, molecular chaperones, and the stress response: evolutionary and ecological physiology. Annu. Rev. Physiol. 61, 243-282. doi: 10.1146/annurev.physiol.61.1.243

Ferguson, G. W., and Fox, S. F. (1984). Annual variation of survival advantage of large juvenile side-blotched lizards, Uta stansburiana: its causes and evolutionary significance. Evolution 38, 342-349. doi: 10.1111/j.1558-5646. 1984.tb00292.x

Fick, S. E., and Hijmans, R. J. (2017). WorldClim 2: new 1-km spatial resolution climate surfaces for global land areas. Int. J. Climatol. 37, 4302-4315. doi: $10.1002 /$ joc.5086

Fish, M. R., Cote, I. M., Gill, J. A., Jones, A. P., Renshoff, S., and Watkinson, A. R. (2005). Predicting the impact of sea-level rise on Caribbean Sea turtle nesting habitat. Conserv. Biol. 19, 482-491. doi: 10.1111/j.1523-1739.2005.00146.x

Foden, W. B., Mace, G. M., Vié, J.-C., Angulo, A., Butchart, S. H., DeVantier, L., et al. (2008). "Species susceptibility to climate change impacts," in The 2008 Review of The IUCN Red List of Threatened Species, eds V. Jean-Christophe, C. Hilton-Taylor, and S. Stuart (Gland: IUCN).

Fuentes, M., Limpus, C., Hamann, M., and Dawson, J. (2010). Potential impacts of projected sea-level rise on sea turtle rookeries. Aquatic Conserv. Mar. Freshwater Ecosystems 20, 132-139. doi: 10.1002/aqc.1088

Gao, J., Zhang, W., Dang, W., Mou, Y., Gao, Y., Sun, B.-J., et al. (2014). Heat shock protein expression enhances heat tolerance of reptile embryos. Proc. $R$. Soc. London B: Biol. Sci. 281:20141135. doi: 10.1098/rspb.2014.1135

Georges, A., Doody, S., Beggs, K., and Young, J. (2004). "Thermal models of TSD under laboratory and field conditions," in Temperature-Dependent Sex Determination in Vertebrates, eds N. Valenzuela and V. Lance (Washington, DC: Smithsonian Books), 79-89.

Gibson, C., de Silva, A., Tognelli, M. F., and Karunarathna, S. (eds) (2020). Assess to Plan: Conservation Action Planning for the Snakes and Lizards of Sri Lanka. Apple Valley, MN: IUCN Conservation Planning Specialist Group.

Gumbs, R., Gray, C. L., Wearn, O. R., and Owen, N. R. (2018). Tetrapods on the EDGE: overcoming data limitations to identify phylogenetic conservation priorities. PLoS One 13:e0194680. doi: 10.1371/journal.pone.0194680

Hawkins, A. J. S. (1995). Effects of temperature change on ectotherm metabolism and evolution: metabolic and physiological interrelations underlying the superiority of multi-locus heterozygotes in heterogeneous environments. J. Thermal Biol. 20, 23-33. doi: 10.1016/0306-4565(94)00023-c

Hertz, P. E., Huey, R. B., and Garland, T. (1988). Time budgets, thermoregulation, and maximal locomotor performance: are reptiles olympians or boy scouts? Am. Zool. 28, 927-938. doi: 10.1093/icb/28.3.927

Hoffmann, A. (2010). Physiological climatic limits in Drosophila: patterns and implications. J. Exp. Biol. 213, 870-880. doi: 10.1242/jeb.037630

Hoffmann, A. A., Chown, S. L., and Clusella-Trullas, S. (2013). Upper thermal limits in terrestrial ectotherms: how constrained are they? Funct. Ecol. 27, 934-949. doi: 10.1111/j.1365-2435.2012.02036.x

Holleley, C. E., O’Meally, D., Sarre, S. D., Graves, J. A. M., Ezaz, T., et al. (2015). Sex reversal triggers the rapid transition from genetic to temperature-dependent sex. Nature 523, 79-82. doi: 10.1038/nature14574

Hoveka, L. N., van der Bank, M., Bezeng, B. S., and Davies, T. J. (2020). Identifying biodiversity knowledge gaps for conserving South Africa's endemic flora. Biodivers. Conserv. 2020, 2803-2819. doi: 10.1007/s10531-020-01998-4

Huang, S. P., Kearley, R. E., Hung, K. W., and Porter, W. P. (2020). NicheMapper; evaporative water loss simulation improves models' prediction of habitat suitability for a high-elevation forest skink. Oecologia 192, 657-669.

Huey, R. B., and Bennett, A. F. (1987). Phylogenetic studies of coadaptation: preferred temperatures versus optimal performance temperatures of lizards. Evolution 41, 1098-1115. doi: 10.2307/2409194

Huey, R. B., Deutsch, C. A., Tewksbury, J. J., Vitt, L. J., Hertz, P. E., Pérez, H. J. Á, et al. (2009). Why tropical forest lizards are vulnerable to climate warming. Proc. R. Soc. London B: Biol. Sci. 276, 1939-1948. doi: 10.1098/rspb.2008.1957

Huey, R. B., Dunham, A. E., Overall, K. L., and Newman, R. A. (1990). Variation in locomotor performance in demographically known populations of the lizard Sceloporus merriami. Physiol. Zool. 63, 845-872. doi: 10.1086/physzool.63.5. 30152617

Huey, R. B., Hertz, P. E., and Sinervo, B. (2003). Behavioral drive versus behavioral inertia in evolution: a null model approach. Am. Natural. 161, 357-366. doi: $10.1086 / 346135$
Huey, R. B., Kearney, M. R., Krockenberger, A., Holtum, J. A., Jess, M., and Williams, S. E. (2012). Predicting organismal vulnerability to climate warming: roles of behaviour, physiology and adaptation. Philos. Trans. R. Soc. B: Biol. Sci. 367, 1665-1679. doi: 10.1098/rstb.2012.0005

Huey, R. B., and Kingsolver, J. G. (1989). Evolution of thermal sensitivity of ectotherm performance. Trends Ecol. Evol. 4, 131-135. doi: 10.1016/01695347(89)90211-5

Huey, R. B., Losos, J. B., and Moritz, C. (2010). Are lizards toast? Science 328, 832-833. doi: $10.1126 /$ science. 1190374

Huey, R. B., and Stevenson, R. (1979). Integrating thermal physiology and ecology of ectotherms: a discussion of approaches. Am. Zool. 19, 357-366. doi: 10.1093/ icb/19.1.357

Hughes, L. (2000). Biological consequences of global warming: is the signal already apparent? Trends Ecol. Evol. 15, 56-61. doi: 10.1016/s0169-5347(99)01764-4

Hutton, J. (1987). Incubation temperatures, sex ratios and sex determination in a population of Nile crocodiles (Crocodylus niloticus). J. Zool. 211, 143-155. doi: 10.1111/j.1469-7998.1987.tb07458.x

IPCC (2019). "Summary for policymakers," in IPCC Special Report on the Ocean and Cryosphere in a Changing Climate, eds H.-O. Pörtner, D. C. Roberts, V. Masson-Delmotte, P. Zhai, M. Tignor, E. Poloczanska, et al. (Geneva: IPCC).

Irschick, D. J., and Garland, T. J. (2001). Integrating function and ecology in studies of adaptation: investigations of locomotor capacity as a model system. Ann. Rev. Ecol. Systemat. 32, 367-396. doi: 10.1146/annurev.ecolsys.32.081501.114 048

Janzen, F. J. (1993). The influence of incubation temperature and family on eggs, embryos, and hatchlings of the smooth softshell turtle (Apalone mutica). Physiol. Zool. 66, 349-373. doi: 10.1086/physzool.66.3.30163 697

Janzen, F. J. (1994). Climate change and temperature-dependent sex determination in reptiles. Proc. Natl. Acad. Sci. U S A. 91, 7487-7490. doi: 10.1073/pnas.91.16. 7487

Ji, X., Chen, F., Du, W. G., and Chen, H. L. (2003). Incubation temperature affects hatchling growth but not sexual phenotype in the Chinese soft-shelled turtle, Pelodiscus sinensis (Trionychidae). J. Zool. 261, 409-416. doi: 10.1017/ s0952836903004266

Karunarathna, S., Amarasinghe, A. T., Henkanaththegedara, S., Surasinghe, T., Madawala, M., Gabadage, D., et al. (2017). Distribution, habitat associations and conservation implications of Sri Lankan freshwater terrapins outside the protected area network. Aquatic Conserv. Mar. Freshwater Ecosystems 27, 13011312. doi: $10.1002 /$ aqc. 2792

Karunarathna, S., de Silva, A., Botejue, M., Gabadage, D., Somaratna, L., Hettige, A., et al. (2019). Three new species of day geckos (Reptilia: Gekkonidae: Cnemaspis Strauch, 1887) from isolated granite cave habitats in Sri Lanka. Amphibian Reptile Conserv. 13, 323-354.

Kellogg, W. W. (2019). Climate Change and Society: Consequences of Increasing Atmospheric Carbon Dioxide. Milton Park: Routledge.

Kubisch, E. L., Fernandez, J. B., and Ibargüengoytía, N. R. (2011). Is locomotor performance zoptimized at preferred body temperature? a study of Liolaemus pictus argentinus from northern Patagonia, Argentina. J. Thermal Biol. 36, 328-333. doi: 10.1016/j.jtherbio.2011.06.006

Leal, M., and Gunderson, A. R. (2012). Rapid change in the thermal tolerance of a tropical lizard. Am. Natural. 180, 815-822. doi: 10.1086/668 077

Lee, T. M., and Jetz, W. (2008). Future battlegrounds for conservation under global change. Proc. R. Soc. B: Biol. Sci. 275, 1261-1270. doi: 10.1098/rspb.2007.1732

Low, T. (2007). "Warming, invasive pests and birds," in The State of Australia's Birds 2007, ed. P. Olsen (Victoria: Birds in a Changing Climate, Birds Australia, Carlton).

Lutterschmidt, W. I., and Hutchison, V. H. (1997a). The critical thermal maximum: data to support the onset of spasms as the definitive end point. Can. J. Zool. 75, 1553-1560. doi: 10.1139/z97-782

Lutterschmidt, W. I., and Hutchison, V. H. (1997b). The critical thermal maximum: history and critique. Can. J. Zool. 75, 1561-1574. doi: 10.1139/z97783

Mair, L., Bennun, L. A., Brooks, T. M., Butchart, S. H. M., Bolam, F. C., Burgess, N. D., et al. (2021). A metric for spatially-explicit contributions to science-based species targets. Nat. Ecol. Evol. 5, 836-844. doi: 10.1038/s41559-021-01432-0 
Mazaris, A. D., Kallimanis, A. S., Sgardelis, S. P., and Pantis, J. D. (2008). Do long-term changes in sea surface temperature at the breeding areas affect the breeding dates and reproduction performance of mediterranean loggerhead turtles? Implications for climate change. J. Exp. Mar. Biol. Ecol. 367, 219-226. doi: 10.1016/j.jembe.2008.09.025

Mazaris, A. D., Matsinos, G., and Pantis, J. D. (2009). Evaluating the impacts of coastal squeeze on sea turtle nesting. Ocean Coastal Manag. 52, 139-145. doi: 10.1016/j.ocecoaman.2008.10.005

Mazzotti, F. J., and Brandt, L. A. (1994). "Ecology of the American alligator in a seasonally fluctuating environment," in Everglades: The Ecosystem and its Restoration, eds D. Davis and J. Ogden (Delray Beach, FL: St. Lucie Press).

McMahon, C. R., and Hays, G. C. (2006). Thermal niche, large-scale movements and implications of climate change for a critically endangered marine vertebrate. Global Change Biol. 12, 1330-1338. doi: 10.1111/j.1365-2486.2006. 01174.x

Miles, D. B. (2004). The race goes to the swift: fitness consequences of variation in sprint performance in juvenile lizards. Evol. Ecol. Res. 6, 63-75.

Miller, K., and Packard, G. C. (1992). The influence of substrate water potential during incubation on the metabolism of embryonic snapping turtles (Chelydra serpentina). Physiol. Zool. 65, 172-187. doi: 10.1086/physzool.65.1.30158 245

Ministry of Mahaweli Development and Environment (2019). Biodiversity Profile - Sri Lanka, Sixth National Report to the Convention on Biological Diversity, Biodiversity Secretariat, Ministry of Mahaweli Development and Environment, Sri Lanka. Battaramulla: Ministry of Mahaweli Development and Environment.

Monasterio, C., Shoo, L. P., Salvador, A., Iraeta, P., and Díaz, J. (2013). High temperature constrains reproductive success in a temperate lizard: implications for distribution range limits and the impacts of climate change. J. Zool. 291, 136-145. doi: 10.1111/jzo.12057

Moreno-Rueda, G., Pleguezuelos, J. M., Pizarro, M., and Montori, A. (2012). Northward shifts of the distributions of Spanish reptiles in association with climate change. Conserv. Biol. 26, 278-283. doi: 10.1111/j.1523-1739.2011. 01793.x

Mulrennan, M. E., and Woodroffe, C. (1998). Saltwater intrusion into the coastal plains of the Lower Mary River. Northern Territory, Australia. J. Environ. Manage. 54, 169-188. doi: 10.1006/jema.1998.0229

Nelson, N. J., Thompson, M. B., Pledger, S., Keall, S. N., and Daugherty, C. H. (2004). Do TSD, Sex Ratios, and Nest Characteristics Influence the Vulnerability of Tuatara to Global Warming? in International Congress Series. Amsterdam: Elsevier.

Nicholls, R. J., Marinova, N., Lowe, J. A., Brown, S., Vellinga, P., De Gusmao, D., et al. (2011). Sea-level rise and its possible impacts given a 'beyond $4^{\circ} \mathrm{C}$ 'world'in the twenty-first century. Philos. Trans. R. Soc. London A: Mathemat. Phys. Eng. Sci. 369, 161-181. doi: 10.1098/rsta.2010.0 291

Noble, D. W., Stenhouse, V., and Lisa, E. S. (2017). Developmental temperatures and phenotypic plasticity in reptiles: a systematic review and meta-analysis. Biol. Rev. 93, 72-97. doi: 10.1111/brv.12333

Parker, S. L., and Andrews, R. M. (2007). Incubation temperature and phenotypic traits of Sceloporus undulatus: implications for the northern limits of distribution. Oecologia 151, 218-231. doi: 10.1007/s00442-006-05 83-0

Parmesan, C., and Yohe, G. (2003). A globally coherent fingerprint of climate change impacts across natural systems. Nature 421, 37-42. doi: 10.1038/ nature 01286

Pike, D. A., Antworth, R. L., and Stiner, J. C. (2006). Earlier nesting contributes to shorter nesting seasons for the loggerhead seaturtle. Caretta caretta. J. Herpetol. 40, 91-94. doi: 10.1670/100-05n.1

Pounds, J. A., Fogden, M. P., and Campbell, J. H. (1999). Biological response to climate change on a tropical mountain. Nature 398, 611-615. doi: 10.1038/ 19297

Rall, J. A., and Woledge, R. C. (1990). Influence of temperature on mechanics and energetics of muscle contraction. Am. J. Physiology-Regulatory Int. Comp. Physiol. 259, 197-203.

Roosenburg, W. M., and Kelley, K. C. (1996). The effect of egg size and incubation temperature on growth in the turtle, Malaclemys terrapin. J. Herpetol. 30, 198-204. doi: $10.2307 / 1565510$
Root, T. L., Price, J. T., Hall, K. R., Schneider, S. H., Rosenzweig, C., and Pounds, J. A. (2003). Fingerprints of global warming on wild animals and plants. Nature 421, 57-60. doi: 10.1038/nature01333

Sillero, N. (2011). What does ecological modelling model? a proposed classification of ecological niche models based on their underlying methods. Ecol. Modell. 222, 1343-1346. doi: 10.1016/j.ecolmodel.2011.01.018

Sinervo, B., Mendez-De-La-Cruz, F., Miles, D. B., Heulin, B., Bastiaans, E., Villagrán-Santa Cruz, M., et al. (2010). Erosion of lizard diversity by climate change and altered thermal niches. Science 328, 894-899. doi: 10.1126/science. 1184695

Sørensen, J. G. (2010). Application of heat shock protein expression for detecting natural adaptation and exposure to stress in natural populations. Curr. Zool. 56, 703-713. doi: 10.1093/czoolo/56.6.703

Southwood, A., and Avens, P. B. (2010). Physiological, behavioral, and ecological aspects of migration in reptiles. J. Comp. Physiol. 180, 1-23. doi: 10.1007/ s00360-009-0415-8

Spotila, J. R., Zimmerman, L. C., Binckley, C. A., Grumbles, J. S., Rostal, D. C., List, A. Jr., et al. (1994). Effects of incubation conditions on sex determination, hatching success, and growth of hatchling desert tortoises. Gopherus agassizii. Herpetol. Monographs 8, 103-116. doi: 10.2307/1467074

Stocker, T., Qin, D., Plattner, G., Tignor, M., Allen, S., Boschung, J., et al. (2013). IPCC, 2013: Climate Change 2013: The Physical Science Basis. Contribution of Working Group I to the Fifth Assessment Report of the Intergovernmental Panel on Climate Change. Cambridge: Cambridge University Press.

Swoap, S. J., Johnson, T. P., Josephson, R. K., and Bennett, A. F. (1993). Temperature, muscle power output and limitations on burst locomotor performance of the lizard Dipsosaurus dorsalis. J. Exp. Biol. 174, 185-197. doi: 10.1242/jeb.174.1.185

Tewksbury, J. J., Huey, R. B., and Deutsch, C. A. (2008). Putting the heat on tropical animals. Science 320, 1296-1297. doi: 10.1126/science.1159328

Thomas, C. D., Cameron, A., Green, R. E., Bakkenes, M., Beaumont, L. J., Collingham, Y. C., et al. (2004). Extinction risk from climate change. Nature 427, 145-148.

Trnik, M., Albrechtová, J., and Kratochvíl, L. (2011). Persistent effect of incubation temperature on stress-induced behavior in the Yucatan banded gecko (Coleonyx elegans). J. Comp. Psychol. 125:22. doi: 10.1037/a0021186

Urban, M. C., Richardson, J. L., and Freidenfelds, N. A. (2014). Plasticity and genetic adaptation mediate amphibian and reptile responses to climate change. Evol. Appl. 7, 88-103. doi: 10.1111/eva.12114

Urbina-Cardona, M. N., Blair, M. E., Londono, M. C., Loyola, R., VelasquezTibata, J., Morales-Devia, H., et al. (2019). Species distribution modeling in Latin America: a 25-year retrospective review. Trop. Conserv. Sci. 12:1940082919854058.

Valenzuela, N. (2001). Constant, shift, and natural temperature effects on sex determination in Podocnemis expansa turtles. Ecology 82, 3010-3024. doi: $10.2307 / 2679831$

Valenzuela, N. (2004). Temperature-dependent Sex Determination. Nottingham: Nottingham University Press.

Van Damme, R., Bauwens, D., Braña, F., and Verheyen, R. F. (1992). Incubation temperature differentially affects hatching time, egg survival, and hatchling performance in the lizard Podarcis muralis. Herpetologica 48, 220-228.

Vermeer, M., and Rahmstorf, S. (2009). Global sea level linked to global temperature. Proc. Natl. Acad. Sci. U S A. 106, 21527-21532. doi: 10.1073/pnas. 0907765106

Vitt, L. J., and Caldwell, J. P. (2013). Herpetology: An Introductory Biology of Amphibians and Reptiles. Amsterdam: Elsevier.

Wake, D. B. (2007). Climate change implicated in amphibian and lizard declines. Proc. Natl. Acad. Sci. U S A. 104, 8201-8202. doi: 10.1073/pnas.0702506104

Waldschmidt, S., and Tracy, C. R. (1983). Interactions between a lizard and its thermal environment: implications for sprint performance and space utilization in the lizard Uta stansburiana. Ecology 64, 476-484. doi: 10.2307/1939 967

Walther, G.-R., Post, E., Convey, P., Menzel, A., Parmesan, C., Beebee, T. J., et al. (2002). Ecological responses to recent climate change. Nature 416, 389-395.

Warner, D. A., Moody, M. A., and Telemeco, R. S. (2011). Is water uptake by reptilian eggs regulated by physiological processes of embryos or a passive hydraulic response to developmental environments? Comp. Biochem. 
Physiol. Part A: Mol. Int. Physiol. 160, 421-425. doi: 10.1016/j.cbpa.2011.07. 013

Webb, G. J., and Cooper-Preston, H. (1989). Effects of incubation temperature on crocodiles and the evolution of reptilian oviparity. Am. Zool. 29, 953-971. doi: $10.1093 / \mathrm{icb} / 29.3 .953$

Webb, J. K., and Whiting, M. J. (2005). Why don't small snakes bask? Juvenile broad-headed snakes trade thermal benefits for safety. Oikos 110, 515-522. doi: 10.1111/j.0030-1299.2005.13722.x

Williams, S. E., Shoo, L. P., Isaac, J. L., Hoffmann, A. A., and Langham, G. (2008). Towards an integrated framework for assessing the vulnerability of species to climate change. PLoS Biol. 6, 2621-2626. doi: 10.1371/journal.pbio.006 0325

Witt, M. J., Penrose, R., and Godley, B. J. (2007). Spatio-temporal patterns of juvenile marine turtle occurrence in waters of the European continental shelf. Mar. Biol. 151, 873-885. doi: 10.1007/s00227-0060532-9

Woolrich-Piña, G. A., Lemos-Espinal, J. A., Smith, G. R., Oliver-López, L., CorreaSánchez, F., Altamirano-Álvarez, T. A., et al. (2012). Thermal ecology of the lizard Sceloporus gadoviae (Squamata: Phrynosomatidae) in a semiarid region of southern Puebla. Mexico. J. Herpetol. 11, 21-27. doi: 10.11606/issn.23169079.v11i1p21-27
Zubair, L., Siriwardhana, M., Chandimala, J., and Yahiya, Z. (2008). Predictability of Sri Lankan rainfall based on ENSO. Int. J. Climatol. 28, 91-101. doi: 10.1002/ joc. 1514

Conflict of Interest: The authors declare that the research was conducted in the absence of any commercial or financial relationships that could be construed as a potential conflict of interest.

Publisher's Note: All claims expressed in this article are solely those of the authors and do not necessarily represent those of their affiliated organizations, or those of the publisher, the editors and the reviewers. Any product that may be evaluated in this article, or claim that may be made by its manufacturer, is not guaranteed or endorsed by the publisher.

Copyright (C) 2021 Dayananda, Bezeng, Karunarathna and Jeffree. This is an openaccess article distributed under the terms of the Creative Commons Attribution License (CC BY). The use, distribution or reproduction in other forums is permitted, provided the original author(s) and the copyright owner(s) are credited and that the original publication in this journal is cited, in accordance with accepted academic practice. No use, distribution or reproduction is permitted which does not comply with these terms. 